\title{
ADAPT AND OVERCOME: REVISING US NAVAL DOCTRINE AND POLICY IN AN ERA OF UNCONVENTIONAL CONFLICT
}

\author{
Professor Adam B. Lowther ${ }^{1}$ \\ Assistant Professor of Political Science, Arkansas Tech University
}

\section{Introduction}

When the Quadrennial Defense Review (QDR) was released in February of 2006, the United States was in the middle of a multi-front Global War on Terror (GWOT) that had been underway for more than four years. Beginning with the initial response to the 9/11 attacks in October of 2001, the US Navy began to play a significant part in the unconventional operations that characterised the early days of OPERATION ENDURING FREEDOM. While the Navy carried out its mission admirably supporting Special Operations Forces (SOF) by providing the USS Kitty Hawk (CV 63) as a "lily pad", which enabled Rangers, Delta operators, Green Berets, and SEALs to move in and out of Afghanistan from a maritime staging area, it was a role well outside the norm of American naval operations and one the Navy is yet to fully embrace. ${ }^{2}$

Without a peer competitor to challenge it, the US Navy has been forced to take on a new role in the current era of asymmetry that is still developing as the Chief of Naval Operations and other senior leaders attempt to adapt to the most recent trend in conflict: asymmetry. In looking toward the future shape of American naval forces, the $Q D R$ and other recent Department of Defense and Bush administration policy documents provide a glimpse of the direction in which the Pentagon is attempting to move the defence and security establishment. For the US

\footnotetext{
${ }^{1}$ Adam B. Lowther is the author of Americans and Asymmetric Conflict: Lebanon, Somalia and Afghanistan. He served in the US Navy/Naval Reserve from 19942000 and as a contractor in 2004-5.

${ }^{2}$ Since the days of the Cold War, SEAL teams have operated with the fleet and launched missions from American war ships, but, much like the combined arms branches of the US Army that dominate the "regular" Army, special forces and the role they play in peace and war have never been fully accepted by officer corps of the US Navy.
} 
Navy to remain a key player and keep its seat at the table, its approach to warfare must adapt or become irrelevant.

The pages that follow examine the QDR, National Intelligence Strategy (2005), Key Judgments of the National Intelligence Estimate (2006) and, briefly, the theoretical work of Alfred Thayer Mahan, Julian Corbett, and Carl von Clausewitz in order to derive a set of suggested modifications to the "Navy way of war". The latter way of war has seen little change in more than a century which threatens the relevance of the US Navy in much the same way as the Royal Navy's failure to adapt to changing circumstances prior to the onset of the Great War threatened its relative dominance of the sea lanes. This is not to suggest that the US Navy is in no way adapting to the current "era of asymmetry". I highlight the creation of the Navy Expeditionary Combat Command (NECC) as a step in the right direction, but there is much more that can be done to ensure that the Navy, like the Army, is prepared for the conflicts of tomorrow. In addition to examining recent military and security policy, I examine the work of Mahan and Corbett and suggest that their work is less relevant during periods in which conflict is largely asymmetric, unconventional forms of warfare such as terrorism, insurgency, and low-intensity conflict dominating the American experience. Instead, I suggest that the work of Clausewitz and his discussion of partisan warfare provide a better source for innovation in naval policy. ${ }^{3}$ By shedding the strictures of Mahanian influence it is possible for the US Navy to play an unprecedented role in current and future conflicts.

Prior to my examination of Mahan, Corbett and Clausewitz, I offer four areas in which significant policy change is necessary for the US Navy to play a vital role in the GWOT and future conflicts which will share many of the same characteristics. Firstly, I suggest that the US Navy expands its unique role in maritime intelligence gathering and analysis. Secondly, as the United States slowly withdraws from its Cold War military bases and continues to face a mobile and elusive enemy, there is an increasing need for mobile maritime basing. Thirdly, the US Navy should expand its role in disaster, humanitarian, and security assistance when and where the opportunity arises in order to prevent the failure of weak states and to build goodwill toward the United States around the globe. Finally, American sailors need to return to their historical role as small-scale urban warriors who, when called upon, possess the training and ability to support marines in small-scale missions or to perform such missions independently.

${ }^{3}$ A full discussion of Mahan, Corbett and Clausewitz is well beyond the scope of this article, which provides a brief description of a small portion of their combined work. 
Because of the range of issues discussed in the pages that follow, it is impossible to fully explore each point in detail. Such is not the objective of this article. Instead, I seek to expand the debate and spur further discussion and research in areas that are often outside the box of accepted debate. In 1911 Julian Corbett, a lawyer by profession, published his treatise on naval doctrine and strategy. He was universally dismissed by the British Admiralty as an amateur dabbling in things he did not understand. Yet, by the end of the Great War, it was Corbett who was revered for his foresight. ${ }^{4}$

\section{Strategic objectives of the Quadrennial Defense Review}

In the wake of the terrorist attacks of September 11, 2001, the Bush administration, with Donald Rumsfeld at the Pentagon's helm, began to envision a force structure that differed dramatically from the post-Cold War navy envisioned by former Secretary of Defense, William Cohen, who began what has been called "force transformation". The release of the 2002 QDR was the Pentagon and Secretary Rumsfeld's initial attempt at moving the American military to a structure suitable for conflicts requiring light, rapidly deployable forces. By the time the latest $Q D R$ was released in 2006, significant change was underway, giving American forces new tools to continue the process of increasing the versatility and combat effectiveness of the average soldier or marine. This theme was continued in 2006, with the advantage of five years of experience in asymmetric conflicts in Afghanistan and Iraq.

Given the American experience in these conflicts, the strategic objectives of the $Q D R$ are not unexpected. Objectives include:

- defeating terrorist networks;

- defending the homeland in depth;

- $\quad$ shaping the choices of countries at strategic crossroads; and

- preventing hostile states and non-state actors from acquiring or using WMD. ${ }^{1}$

\footnotetext{
${ }^{4}$ When it was suggested to the Admiralty during the Great War that convoy operations were necessary, the admirals rejected the idea because they considered it a violation of Mahan's principle of concentration of force and aggressive action. It was only at Prime Minister David Lloyd George's insistence that convoy operations were undertaken by the Royal Navy. See Martin van Creveld, The Changing Face of War (New York: Presidio Press, 2007) p. 61.
} 
The report continues, "The long war against terrorist networks extends far beyond the borders of Iraq and Afghanistan and includes many operations characterised by irregular warfare-operations in which the enemy is not a regular military force of a nation state". ${ }^{2}$ Preventing weak states from becoming havens for terrorist networks plays an important role in the strategic outlook of the Pentagon. By assisting states facing natural disasters, economic difficulties and unstable security environments, there is a clear expectation that American efforts will lead to a closer relationship with the recipient-state, which will promote support for the American-led Global War on Terrorism (GWOT). These objectives provide opportunity for the US Navy to expand its role in each of these areas. As the single branch of the US military that is not concentrated in Iraq and Afghanistan it has the greatest opportunity to play a significant role in accomplishing some of these goals in distant lands.

Additionally, the $Q D R$ highlights the need for increased freedom of action for American troops. Thus, a major effort is currently underway to reduce the number of servicemen and women based in Europe, Korea and Japan. A preference for deploying smaller combat-ready units who can assist local forces in defeating terrorists or threats to stability is present in the $Q D R$ 's broader strategic outlook. Returning American servicemen to the continental United States will not only alleviate many of the political problems that developed as a result of the Iraq War, but will provide substantial cost savings to the Pentagon as it faces an increasingly expensive war in Iraq.

\section{Expanding the role of the US Navy}

For the United States, conflict in the coming decades is highly unlikely to be large-scale conventional warfare. While the $Q D R$ acknowledges that the People's Republic of China (PRC) will continue to develop as the next peer competitor of the United States, parity and the prospect of engaging the Chinese in a large-scale conflict, on land or sea, is decades in the future if such a threat ever materialises. Therefore, I suggest that the Navy would be wise to advance its capabilities in four key operational areas: intelligence gathering and analysis, forward deployed basing, disaster, small-scale urban combat, and humanitarian and security assistance. In addition, these recommendations require significant revisions to current naval policy and doctrine which are predicated on the brilliant yet outdated strategic thought of Mahan and Corbett, which were relevant until the collapse of the Soviet Union, and which may be relevant again should, for instance, China develop a navy capable of challenging the US Navy. 
As Martin van Creveld has noted in his discussion of naval warfare during World War II, "Correctly applied, World War II—style air-and sea power could help a ground army carry out specific operations and push them to conclusion. However, neither at sea nor in the air could there be any question of a single climactic battle that, by rendering the opponent defenseless and breaking his will, decide the issue. Even the battle of Leyte Gulf, the largest ever fought at sea, did not mark more than one stage in the destruction of the Japanese navy ..." "V Van Creveld's statement is of greater relevance in the current era where the scale of conflict never approaches that of World War II. Thus, a US Navy designed to win such a battle is, perhaps, not the most efficient use of resources, even for a hegemon such as the United States.

\section{Intelligence gathering and analysis}

Among the most underappreciated roles of the US Navy is its function in patrolling the sea lanes, which requires the constant deployment of naval asset around the world. The steady contact the fleet has with maritime shipping, foreign navies, and host governments where port calls are made provides an opportunity to expand the human relationships naval intelligence has with military and civilian intelligence personnel around the globe. Where the United States possessed insufficient human intelligence capabilities prior to $9 / 11$, the Navy has the opportunity to expand its own formal and informal networks, which remain among the poorest in the American intelligence community. ${ }^{4}$ Relying on non-maritime intelligence services for gathering human intelligence dramatically limits the intelligence that can directly impact the performance of naval operations. Given the specialised nature of maritime missions (shipping, maritime terrorism, human trafficking, and transport, etc.), intelligence analysts and operations officers lacking specialised training and concern in maritime intelligence are likely to overlook information that may prove vital to the success of fleet operations.

Further clarification underscores this point. In the first instance, CIA operations officers rarely possess backgrounds in the SEALs, Naval Intelligence, or Naval Criminal Investigative Service (NCIS), which leaves intelligence collection and asset acquisition underdeveloped in areas that are most likely to provide the necessary intelligence to, for example, prevent the maritime transportation of weapons of mass destruction (WMD) or prevent the next USS Cole (DDG-67)-style attack or its variant. In many instances, these collectors are not looking for intelligence that would be useful in maritime counterterrorism efforts. An expanded Naval Intelligence role is likely to develop relationships with a range of potential assets that CIA operations officers, for example, are unlikely to ever contact and 
develop. They may range from commercial ship captains to foreign naval officers, who may assist in developing a broader picture of the maritime security environment. As terrorist operatives find it increasingly difficult to travel and move critical material using commercial aircraft, they will certainly turn to maritime transportation as a way to move operatives and material to both host and target countries. Without Naval Intelligence expanding its human intelligence gathering capabilities, useful information will be lost.

While the US Navy has a strong tradition of gathering and decoding signals intelligence through one of the world's most successful cryptological services, modern terrorists were quick to learn that the United States was listening to their phone conversations and reading their email. ${ }^{5}$ Thus, they turned to low-tech solutions that can only be discovered through human intelligence gathering. This becomes more relevant as air travel becomes increasingly secure and maritime transportation is used as an alternative.

Recent efforts by the Department of the Navy to develop a core of Foreign Area Officers (FAO) is a start consistent with the $Q D R$ 's repeated calls that the Department of Defense (DoD) expand the number of active and reserve personnel with the language and cultural skills necessary for American forces to operate in countries supporting ongoing efforts in the Global War on Terror. ${ }^{6}$ This, however, is not enough. Naval Intelligence has long been analysis-driven, but, if the US Navy is to play a major anti-terror role, it must expand its collection capabilities by developing its human intelligence capacity. Shifting naval intelligence officers to the fleet, where there are few, after extensive training in collection methods will dramatically improve maritime intelligence. By developing its collection capacity, the Navy would be fulfilling the mission objectives laid out in the 2005 National Intelligence Strategy and reducing the probability of an attack against the homeland in which a WMD is smuggled into the country through one of the nation's ports, for example. $^{7}$

\section{Forward deployed basing}

With reductions in the number of American servicemen and women stationed at Cold War-era bases in Europe and Asia beginning in the 1990s and continuing after the onset of the Global War on Terror, the US Navy has a unique opportunity to expand its role in providing mobile sea-basing for future expeditionary operations. ${ }^{8}$ The USS Kitty Hawk's (CV 63) lily pad operation during $\mathrm{OEF}$ is but a small-scale example of what is possible if the DoD moves ahead with proposals coming from the Department of the Navy (DoN) in such documents as 
Sea Power 21. If friend and foe continue to resist American efforts in Iraq and elsewhere, foreign bases become as much a liability as an asset as they restrict options available to combat commanders during ongoing operations. As the American experience in Uzbekistan illustrates, host governments can come under significant pressure from their citizenry to end cooperative arrangements with the United States, leaving American forces to scramble to find a new base of operations. $^{9}$

With future conflicts likely to share more in common with the current assistance American special operations forces are providing the Philippines in its struggle against Islamic fundamentalists than the Vietnam or Iraq wars, sea-basing will enable American troops to deploy anywhere in the world for sustained operations while also maintaining a low profile. This may be necessary if the local population is unsupportive of American involvement. In many circumstances, the precarious hold on power that some governments maintain could lead them to forego assistance from the United States if that assistance includes the basing of American troops on their soil. Sea-basing alleviates many of these concerns. A sufficiently developed sea-basing capacity could also support large-scale expeditionary forces capable of supporting operations such as those in Afghanistan or Iraq. ${ }^{10}$

The added speed and flexibility that sea-basing provides makes it an option that cannot be overlooked. As Cold War alliances decline in strength, the United States will pursue a foreign policy that is sometimes inconsistent with the preferences of our European allies. The independence of action a developed seabasing capacity provides places the United States in the best position to act in its interests around the globe.

\section{Disaster, humanitarian, and security assistance}

When the Sumatra-Andaman earthquake shook the ocean floor off the coast of Sumatra in the early morning hours of December 26, 2004, there were few inhabitants or tourists in Southeast Asia who felt the quake or knew that it caused a tsunami that would ultimately kill 299866 people in Thailand, Indonesia, Sri Lanka and India. Once the initial devastation was over, the international community began to quickly descend to the scene. Among the first to respond were American warships, which performed a number of humanitarian missions: supplying food and water to inhabitants of the devastated areas, searching for survivors washed into the ocean by the receding waves, and a number of other tasks. ${ }^{11}$ Providing disaster and 
humanitarian assistance to the devastated region in the weeks and months following the tsunami was not the first time the US Navy assisted those in need.

The Navy has a long and storied tradition of providing help to injured or stranded sailors, rescuing or providing security to Americans in foreign countries, assisting the inhabitants of devastated areas, and performing humanitarian missions in impoverished countries where the Navy makes port calls. With approximately half of the nearly 300-ship navy deployed at any given time, small contingents of American sailors and marines are in regular contact with citizens of other nations. ${ }^{12}$ This is an opportunity for the United States to spread goodwill and, when the occasion arises, to provide disaster and humanitarian assistance. While the Navy has long provided assistance where needed, making such activity a stated element of naval strategy will raise its importance and increase the role such missions play in the Navy's larger objectives.

Such operations are consistent with the broader goals of the 2006 Quadrennial Defense Review which states, "By alleviating suffering and dealing with crises in their early stages, U.S. forces help prevent disorder from spiraling into conflict or crisis". The small-scale missions performed by sailors volunteering their free time in port, a squadron or battle group responding to a disaster, or simple assistance provided to a vessel in distress generates goodwill toward the United States that often provides much greater benefits than costs.

\section{Small-scale urban combat}

In a move that received little attention, the Navy Expeditionary Combat Command (NECC) was created on January 14, 2006. The new command will "consolidate the current missions and functions of the 1st Naval Construction Division, Naval Expeditionary Logistics Support Force, and Maritime Force Protection Command". ${ }^{13}$ More than 40000 sailors will join the NECC as the Navy begins to transform itself for the antiterrorism and personnel protection mission of the future. Naval Construction Battalions (including Underwater Construction Teams), the Explosive Ordinance Disposal community, naval coastal warfare groups, masters-at-arms, and expeditionary logistics specialists will all join the new command. By the end of 2006 the NECC was tasked to take over brown-water operations in Iraq and to begin to provide port security. Rear Admiral Donald Bullard, the NECC commander, expects the command's mission to grow in the years to come and to include counter-narcotics, anti-piracy, and counterterrorism operations around the globe. ${ }^{14}$ 
The move to join the other services in the asymmetric conflicts of the twenty-first century is a step in the right direction for a service that has traditionally been resistant to change and with a clear preference for large-scale conventional operations. Such resistance to a changing security environment is illustrated by the doctrinal dominance of blue-water operations as the core of naval operations. History, however, offers a different tradition. With few exceptions such as World War I and II, the Navy's experience has not required a large blue-water fleet, which has rarely seen conventional naval combat. Beginning with the quasi-war with France (1799-1801), the United States has engaged in more than two hundred conflicts, which were, with less than a dozen exceptions, small-scale asymmetric conflicts, most frequently smaller than the wars in Afghanistan and Iraq today. ${ }^{15}$ In engagements from Tripoli (1801-1805) to the war in Iraq (2003-present), sailors serve(d) as boarding parties, constabulary troops, light infantry, security forces, peacekeepers, and in a number of other capacities outside their role aboard ship. Past generations of sailors were better prepared for these missions than today's sailors, who have been transformed into technical experts, engineers, and other support staff with little capability to engage in the land combat that was once a significant aspect of the profession.

This transformation is an outcome of the Navy's commitment to technological innovation, which has made the US Navy the world's greatest standoff force, capable of sending a Tomahawk through an opened window at the Iraqi Interior Ministry more than a thousand miles away. While there is much to be proud of, technology does not change the nature of warfare or the need for sailors capable of joining their marine brethren in combat ashore. ${ }^{16}$ Just as sailors served as infantrymen in the Marqueses Islands (1813-1814), Cuba (1823) and Greece (1827), the need still exists for Bluejackets who can engage in land combat. As the United States's forward-deployed forces, warships on regular deployment spread American influence across the globe and are often the only personnel capable of rapidly responding to incidents where the use of force is appropriate. Today, however, sailors are ill-prepared to act in the capacity that was once a common aspect of their job.

Two reasons explain the decline of ground combat proficiency. First, American naval doctrine is dominated by Mahan and, to a lesser degree, Corbett, who saw no role for the Navy in combat on shore. Second, without an obvious rival, the Department of the Navy views the primary role of the fleet as a standoff strike force and as the provider of security to the sea lanes. The preference for technically savvy sailors who lack the training to perform small-scale combat operations has left the Navy ill-prepared to play a larger role in modern warfare. 
While Mahan and Corbett were among the greatest naval strategists to examine maritime combat, neither offers a suitable solution for the asymmetric conflict that is likely to dominate the twenty-first century. This is in contrast to the work of Clausewitz, who, despite his experience at the height of the linear era, understood the role of asymmetry in warfare. Admittedly, Clausewitz was a soldier who ignored maritime operations, but in critiquing the greatest naval strategists of all time, it is only appropriate to offer an alternative from the thought of an equal to Mahan and Corbett.

After briefly illustrating the weaknesses of Mahan and Corbett in the following section, I contrast their work with Clausewitz's discussion of partisan warfare, which offers useful principles that can bear relevance for American naval doctrine as the US Navy adapts to current and future modes of warfare.

\section{Alfred Thayer Mahan and Julian Corbett}

Rear Admiral Alfred Thayer Mahan, a veteran of the Civil War (18611865 ) and the first president of the Naval War College, remains one of history's most influential naval theorists. His first and greatest work, The Influence of Sea Power upon History, 1660-1783 (1890), is widely regarded as the most influential treatise on naval strategy ever written. ${ }^{17}$ Mahan, a prolific writer and student of Baron Antoine-Henri de Jomini, applied the linear concepts of the Swiss strategist to naval combat, suggesting that naval warfare, like land warfare, follows a set of timeless principles. ${ }^{18}$ Primary among these principles is the need for great powers to maintain supremacy of the seas. In doing so, great powers are able to ensure the free flow of trade, which enriches a nation. Mahan gained his earliest insight from a reading of the history of the Second Punic War (218-201 BC). ${ }^{19}$ There, Carthage and Hannibal were restrained in their ability to wage war against Rome because of the Empire's dominance of the Mediterranean. Realising the significant role sea power played in the ultimate defeat of Carthage, Mahan began his study of the influence of British sea power in the seventeenth and eighteenth centuries.

Taking up the central premise of Jomini, Mahan viewed the key to winning naval supremacy as the concentration of (naval) force at the decisive point of battle. Thus, Mahan was an advocate of major naval engagements that lead either to total victory or total defeat. Rather than viewing great power navies as supporting services, Mahan believed them to be the key to economic, military and political dominance. ${ }^{20}$ Not only do they engage the enemy, but navies ensure the free flow of goods, destroy enemy trade, blockade enemy ports, transport troops, and keep the 
lines of communication open between colonial possessions and the metropole. ${ }^{21}$ The central significance of the navy in warfare is understandable, given Mahan's career as a naval officer and his leadership of the Naval War College. Nor is it unexpected that the Navy has continued to focus on Mahanian strategy.

Throughout his writings, Mahan remains focused on the great power rivalries of his day. He displays little grasp of the concept of asymmetry, despite the history of the US Navy which was dominated by small-scale conflicts from its earliest days. At the time of Mahan's writing, the US Navy had been successful in operations ranging from protecting or evacuating Americans abroad to punitive expeditions. It had not, however, fought a large-scale naval conflict. In ignoring the American naval experience, Mahan left all but the greatest navies of the world without useful strategic advice.

British naval historian Julian Corbett, a contemporary of Mahan, differs greatly in his conception of the role of naval forces in warfare. Corbett's most influential work, Some Principles of Maritime Strategy (1911), directly challenges Mahan's concept of the navy's role in warfare. ${ }^{22}$ Unlike Mahan, Corbett viewed the navy as a service with the primary role of supporting land combat. Where Mahan and the British Admiralty believed that the Royal Navy should seek the decisive battle, Corbett proposed a more limited role for navies. Contrary to Jomini, who advocated concentrating force at the decisive point of battle, Corbett rejected the concentration of force, which remains an element of naval combat doctrine well into the twenty-first century. ${ }^{23}$

He regarded concentration as a poor strategy for maintaining command of the sea. Three reasons illustrate why. First, when naval forces are concentrated, an adversary may more easily refuse battle by flight. Second, dispersing naval forces creates an element of shapelessness and surprise, which cannot be achieved by concentration. Third, when concentration is a principle of naval combat, flexibility of action is diminished. ${ }^{24}$

Limited naval engagement, according to Corbett, is the dominant form of maritime warfare. Thus, it is imperative to fight on one's own terms rather than those of the enemy. Additionally, limited conflicts should be fought in such a way that the greatest gains are made at the lowest costs. This translates into support for the strategic offensive, which relies on taking offensive action when risks are low and gains high. The strategic offensive serves as a force multiplier, greatly increasing the effective strength of naval forces. ${ }^{25}$ 
The strategic and tactical innovations of Mahan and Corbett, while often diametrically opposed, included no conception of naval warfare as an element of asymmetric conflict. Mahan's fixation with total warfare left little room for the small-scale asymmetric conflicts of the twenty-first century. Although Corbett's elements of surprise, flexibility and shapelessness were significant aspects of asymmetric conflict, and come closest to describing current warfare, he failed to anticipate the use of maritime assets by partisans, guerrillas and terrorists, or the way naval assets may be used to defeat such adversaries.

Neither of the strategists offers insight relevant to the study of asymmetric conflict. Their focus on state actors precluded them from viewing non-state actors as major threats, requiring naval assets to engage in unconventional forms of warfare. When considering the histories of the American and British navies, whose nineteenth century experience often included small-scale land combat, this oversight of Mahan and Corbett is ironic.

It, however, would have been difficult for Mahan or Corbett to anticipate events such as the hijacking of the Achille Lauro in October 1985 or the bombing of the USS Cole in October 2000. For both theorists, naval combat belonged to the nation-state alone. Thus, in the modern day, naval doctrine offers great potential for innovation as asymmetric actors seek new ways to minimise the advantage major power navies provide the state. The proverbial box in which Mahan and Corbett placed great power navies left room for a theorist of land combat, such as Clausewitz, to offer insights that can be applied to naval strategy.

\section{Carl von Clausewitz}

Originally read by a limited number of Prussian officers, Carl von Clausewitz's On War rose to prominence with the rapid defeat of France in the Franco-Prussian War (1870-1871). In the aftermath of the war, Helmuth Graf von Moltke, chief of the Prussian General Staff, remarked on the influence On War played in the development of his thinking, setting off a wave of interest in the work of Clausewitz.

Unlike his contemporary Jomini, Clausewitz viewed war as an elemental act of violence, which negates social constraints and makes war the arbiter of moral and social norms. ${ }^{26}$ Rather than looking for timeless principles of warfare, which Clausewitz believed to be nonexistent, the Prussian sought to understand the nature of war. Thus, Clausewitz set himself apart from Jomini by emphasising the human elements of war: chance, friction, genius, will and others. ${ }^{27}$ For the Prussian, "War is 
nothing but a duel on a larger scale. Countless duels go to make up war, but a picture of it as a whole can be formed by imagining a pair of wrestlers. Each tries through physical force to compel the other to do his will; his immediate aim is to throw his opponent in order to make him incapable of further resistance". ${ }^{28}$

Clausewitz's concentration on the human elements of war makes $\mathrm{On}$ War timelessly relevant to asymmetric conflict. In addition, Clausewitz understood better than his contemporaries the impact of partisan war on conventional armies. ${ }^{29}$ While serving as a deputy to Prince August at the battle of Auerstedt, Clausewitz ordered one third of his men to fight as skirmishers opposing the flexibility of the French, experiencing his first success with the introduction of asymmetry into conflict. After Prussia's defeat, Clausewitz, in violation of the armistice agreement between France and Prussia, participated in the raising of the home guards, an irregular force of citizen-militia, in order that they might fight as partisans against future French invasion. When he later served as the director of General Scharnhorst's office in Berlin, Clausewitz lectured on partisan warfare. ${ }^{30}$ Contrary to the typical view of Clausewitz as strategist in linear warfare alone, he was also one of Europe's preeminent strategists of partisan, or as it is now called, asymmetric conflict. Applied to naval combat, Clausewitz's discussion of warfare requires a level of flexibility rarely seen in what is the most rigid and tradition-bound of the military services, the navy.

In On War Clausewitz dedicated a chapter to the subject, making him one of the few theorists of his time to develop a thorough understanding of what he labelled "partisan warfare." His counterparts did little more than show their distaste for partisan warfare, dismissing it rather than attempting to understand it. The Prussian's attention to asymmetry is remarkable when the limited role it played in the Napoleonic Wars (1799-1815) is considered. Acknowledging the role asymmetry may play in future conflict contravenes the accepted rules of war and illustrates the depth of Clausewitz's grasp of the military arts. Applied appropriately, the lessons of Clausewitz can assist navies in understanding the nature of the fight waged by the weaker side and the role a major power navy can play in defeating the enemy.

While Clausewitz is perhaps best known for saying, "War is merely the continuation of policy by other means", it is his understanding of the fundamental political nature of war that set him apart from his contemporaries. In viewing war as a political act, Clausewitz spoke directly to the attributes of asymmetric conflict that make it such a difficult task for states to overcome. Although often credited with advocating total war, Clausewitz understood that war is directed by the political 
objectives for which it is undertaken. Thus, Clausewitz was far more flexible in his conception of war than he is often given credited for. ${ }^{31}$

Chapter twenty-six of On War offers great insight into the strategic and tactical requirements and objectives needed to wage partisan warfare, thus offering the naval officer a glimpse into the role he can play in defeating a guerrilla movement or insurgency. In The People in Arms the Prussian treated insurrection as another means of war, which he considered "an outgrowth of the way in which the conventional barriers have been swept away in our lifetime by the elemental violence of war". ${ }^{32}$ Clausewitz begins his discussion by enumerating five conditions under which partisan warfare can be effective:

- The war must be fought in the interior of the country.

- It must be decided by a single stroke. ${ }^{33}$

- The theatre of operations must be fairly large.

- The national character must be suited to that type of war.

- The country must be rough and inaccessible, because of mountains or forests, marshes, or the local methods of cultivation. ${ }^{34}$

In effect, Clausewitz offered a set of characteristics that were adopted by later insurgents. He explained the significance of geography, noting that the greater the degree of difficulty terrain presents, the greater will be the viability of partisan units. ${ }^{35}$ Clausewitz then moved to the deployment of partisans. Illustrating a wellconsidered understanding of the asymmetry of partisan warfare, he advises, "Militia and bands of armed civilians cannot and should not be employed against the main enemy force-or indeed against any sizeable force. They are not supposed to pulverise the core but to nibble at the shell and around the edges". ${ }^{36}$ Clausewitz adds, "A general uprising, as we see it, should be nebulous and elusive; the resistance should never materialize as a concrete body, otherwise the enemy can direct sufficient force at its core, crush it, and take many prisoners. When that happens, the people will lose heart and, believing the issue has been decided and further efforts would be useless, drop their weapons." ${ }^{37}$

Clausewitz continues by further discussing the need for partisan forces to, ultimately, employ conventional tactics to defeat an enemy. ${ }^{38} \mathrm{He}$ adds, "On the other hand, there must be some concentration at certain points: the fog must thicken and form a dark and menacing cloud out of which a bolt of lightning may strike at any time. These points of concentration will, as we have said, lie mainly on the flanks of the enemy's theatre of operations. That is where insurgents should build up larger units, better organized, with parties of regulars that will make them look like a 
proper army and enable them to tackle larger operations." ${ }^{39}$ Clausewitz ends his discussion of large-unit tactics by emphasising the psychological dislocation achieved through large-scale partisan attacks.

Anticipating the Chinese Communists' tactical failure in the Five Encirclements Campaign (1927-1934) and the success of the Long March (1934), Clausewitz warned partisans against turning to the tactical defence for the preservation of geographic gains. He explained the weakness of this static defence, stating, "Moreover, not much is lost if a body of insurgents is defeated and dispersed - that is what it is for. But it should not be allowed to go to pieces through too many men being killed, wounded or taken prisoner: such defeats will soon dampen its ardour." ${ }^{40}$ His grasp of the role played by asymmetric actors is clear: they win by not losing. This point later played a central role in the war waged by Mao and the Chinese Communists against the Kuomintang and continues to this day as Iraqi insurgents undermine the American war effort simply by not being destroyed.

The advice of Clausewitz bears increased relevance in the current global environment, where the overwhelming military supremacy of the United States leads American commanders to a doctrine that seeks to bring adversaries to battle. As Peter R. Moody and Edward M. Collins suggest, modern democracies view war as moral action, which requires direct confrontation with the enemy. This leaves the United States and other Western democracies little room to wage protracted wars against an enemy who refuses to give battle. ${ }^{41}$ In examining Clausewitz's views on partisan warfare in an article devoted to naval doctrine and policy, the objective is to illustrate current limitations while highlighting current theory that may offer relevant alternatives. Where Mahan and Corbett saw great power navies engaging one another, Clausewitz saw great powers engaging non-state actors, albeit on land.

Mahan and Corbett failed to recognise the vital role naval forces play in conflicts of asymmetry. This failure limits the usefulness of American naval doctrine in the twenty-first century. At a recent conference sponsored by the US Navy and attended by its officers, attendees humorously subtitled the conference "200 Years without Change". What they did not realise was the significance of the joke. Despite the Navy's dependence on the latest technological innovation, naval doctrine remains mired in concepts that are less applicable to modern warfare than they were in previous generations. 


\section{Toward an adaptive naval doctrine}

With American military dominance certain to remain in the coming decades, adversaries of the United States will continue to refuse battle. As the 1990s illustrated, targets of opportunity will dominate the threat matrix. The widely deployed ships of the US Navy are likely to be the first to respond in many situations. Revising naval doctrine and policy will better enable the Navy to play a more active role in the asymmetric conflicts, peacekeeping operations, and disaster relief of the future. Reflecting the operational changes discussed above, four areas of strategic change are needed.

Firstly, the preference for large-scale naval combat must be replaced with an understanding of small-scale conflict. Mahanian style engagements are rare in American naval history and have not been seen in more than five decades. Concerns that China will be the next peer competitor to challenge American naval supremacy are founded in a need for a clear adversary and the desire to preserve weapons systems, rather than in a clear threat the People's Republic of China poses now or in the future. ${ }^{42}$ The integration of the Chinese economy into the global economy will continue to moderate military policy in Beijing as the Communist government pursues market-oriented policies in the decades to come. Nor can it be forgotten that China is a nuclear power, which has served as a moderating influence among nuclear states.

Secondly, asymmetric conflict can no longer remain only a problem for the Army, Marine Corps, and Special Operations Forces. The existing perception that asymmetric conflict touches the naval service on the periphery serves only to slow the needed transformation of naval doctrine and policy. Personnel engaged in current asymmetric conflicts, such as the SEALs, EOD, Seabees, masters-at-arms, and riverine units must no longer be viewed as standing outside naval tradition. Rather, the training and skills they possess are vital to preparing fleet sailors for their role in future conflict.

Thirdly, standoff capabilities and technological superiority should not serve as the foundation of naval policy in the twenty-first century. A desire to defeat adversaries of the United States through technological superiority will lead to a deeply flawed conception of conflict that asymmetric actors will exploit as they use a combination of high and low technology to dislocate, disrupt, and defeat American forces. 
Lastly, training must be provided to sailors, enabling them once again to participate in small-scale urban combat operations, riot control, human intelligence gathering, and constabulary policing. This is not to adopt the "every marine a rifleman" approach of the Marine Corps or to suggest an "every sailor a SEAL" approach, but it is a fundamental rejection of the current conception of the sailor as a technical expert with few of the skills of a light infantryman. American naval history and the return to unconventional forms of conflict underscore this point. As microscale conflicts erupt in the years to come, sailors are likely to arrive on scene first and must be capable of responding with direct force when necessary. ${ }^{43}$

By offering this critique of naval doctrine, I seek to offer a path for future innovation in doctrine and policy. Creation of the Navy Expeditionary Combat Command is a first step toward reassessing an outdated understanding of the Navy's role in modern conflict. Contrary to recent comments by Fleet Forces Commander, Admiral Jonathan B. Nathman, who said the NECC "is not about naval infantry", I suggest that there is a need for sailors with a skill set that includes such capabilities. ${ }^{44}$ If the past is to offer lessons for the future, the Navy can no longer sustain the Mahanian doctrine that has dominated it for more than a century. It must adapt or become irrelevant as other services take the steps necessary to adapt and overcome.

\section{End notes}

${ }^{1}$ Donald Rumsfeld, Quadrennial Defense Review (Washington, D.C.: Department of Defense, 2006) p. 3.

${ }^{2}$ Ibid., p.11.

${ }^{3}$ Martin van Creveld, The Changing Face of War (New York: Presidio Press, 2007) p. 171.

${ }^{4}$ For a description of human intelligence weaknesses see, The 9/11 Commission Report (New York: W.W. Norton, 2004) Chapters 11 and 13.

5 "Osama's Satellite Phone Switcheroo", CBS News (January 21, 2003). See also John Keegan, Intelligence in War (New York: Alfred A. Knopf, 2003) Chapter 4.

${ }^{6}$ Steven C. Boraz, "Behind the Curve in Culture-Centric Skills", Proceedings 131 no. 6 (2005). Available at: http://216.230.103.132/ proceedings/ Articles05/Pro06Boraz.htm Accessed on 23 November 2007.

7 John D. Negroponte, National Intelligence Strategy of the United States of America (Washington, D.C.: Office of the Director of National Intelligence, 2005) p.4.

${ }^{8}$ See Henry B. Cook, "Sea-Basing and the Maritime Propositioning Force (Future)", Military Review (July-August 2004) pp. 54-58.

9 Anon. "U.S. Completes Withdrawal from Uzbekistan", (Tashkent, Uzbekistan: MSNBC, November 21, 2005). 
${ }^{10}$ See Charles W. Moore, Jr. and Edward Hanlon, Jr., "Sea Basing: Operational Independence for a New Century”, Proceedings 121 no. 1 (2003) pp. 80-85.

11 Rebecca Ford Mitchell, "U.S. Military Assistance to Tsunami Victims Already Under Way", Department of State (Washington, D.C.: International Information Program, December 28, 2004).

12 Anon. "Tsunami Disasters and the U.S. Navy", (Washington, D.C.: Naval Historical Center, 2005). Available at: http://www.history.navy.mil/faqs/faq1301.htm Accessed on 23 November 2007.

${ }^{13}$ Katrina Scampini, "Navy Expeditionary Combat Command Stands Up", (Norfolk, VA.: Fleet Public Affairs Center Atlantic, January 14, 2006). Available at: http://www.news.navy.mil/search/display.asp?story_id=21962 Accessed on 23 November 2007.

${ }^{14}$ Ibid.

15 See Michael J. Crawford and Christine F. Hughes, "Historical Overview of the Federalist Navy, 1787-1801", in The Reestablishment of the Navy, 1787-1801 Historical Overview and Select Bibliography (Washington, D.C.: Naval Historical Center, 2006). Available at: http://www.history.navy.mil/biblio/biblio4/biblio4.htm Accessed on 23 November 2007. For a detailed list of American conflicts, see Richard F. Grimmett, Instances of United States Armed Forces Abroad, 1798-2004 (Washington, D.C.: Congressional Research Service, 2004).

${ }^{16}$ Martin van Creveld, Technology and War: From 2000 B.C. to the Present (New York: Touchstone, 1991) Chapters 5 and 10.

17 Alfred T. Mahan, The Influence of Sea Power upon History, 1660-1783 (New York: Little Brown \& Co., 1980). The basic premise of Mahan's greatest work is straightforward. Britain won the seventeenth- and early eighteenth-century contest with France because it gained supremacy of the seas and maintained the free flow of goods between Britain and its colonies.

18 See also Alfred T. Mahan, The Influence of Sea Power upon the French Revolution, 1793-1812 (Boston: Little \& Brown, 1892), and Alfred T. Mahan, Armaments and Arbitration (New York: Harper, 1912).

19 Jon Sumida, "New Insights from Old Books", Naval War College Review 54, no. 3 (2001). Available at: http://findarticles.com/p/articles/mi_m0JIW/is_3_54/ ai_80786336 Accessed on 23 November 2007.

${ }^{20}$ Keith Errington and Elizabeth J. Nielson, (eds.), Navies and Global Defense: Theories and Strategy (Westport, Conn.: Praeger, 1995) Chapter 3.

${ }^{21}$ Mahan, The Influence of Sea Power upon History, 1660-1783. pp. 25-28.

22 Julian Corbett, Some Principles of Maritime Strategy (New York: Longman, Green and Company, 1911).

${ }^{23}$ Michael Handel, "Corbett, Clausewitz and Sun Tzu", Naval War College Review 53, no. 4 (2000).

${ }^{24}$ Ibid., p. 3.

25 See Stephen W. Roskill, The Strategy of Sea Power: Its Development and Application (London: Collins, 1962). 
26 Martin van Creveld, The Transformation of War: The Most Radical Reinterpretation of Armed Conflict since Clausewitz (New York: Free Press, 1991) p. 109.

${ }_{27}$ Alan Beyerchen, "Clausewitz, Nonlinearity, and the Unpredictability of War", International Security 17, no. 3 (1992) p. 60, Beyerchen suggests that the human elements of Clausewitz's work make it eternally valid.

${ }^{28}$ Carl von Clausewitz, On War (New York: Alfred A. Knopf, 1993) p. 83.

${ }^{29}$ Clausewitz viewed war primarily as a conventional act between state-sponsored militaries. It is his views on conventional conflict and the totality of war that have enshrined the Prussian theorist in Western military thought. His discussion of partisan or people's war generally receives little attention.

${ }^{30}$ Peter Paret, "Clausewitz", in Makers of Modern Strategy from Machiavelli to the Nuclear Age, (ed.) Peter Paret (Princeton, N.J.: Princeton University Press, 1986) pp. 191-92.

${ }^{31}$ Among Clausewitz's most articulate critics is Martin van Creveld, who challenges the applicability of Clausewitz in the post-Cold War world, suggesting that his conception of total war is inappropriate for the asymmetric conflicts of the twentyfirst century. In Chapter 2 of The Transformation of War, Van Creveld adds that Clausewitz's understanding of war as an elemental act of violence waged by states is as outmoded as his conception of total war.

${ }^{32}$ Clausewitz, On War, p. 578.

${ }^{33}$ In Clausewitz's own time, the defeat of France in Spain took many small engagements to slowly destroy French forces. Conventional battles between AngloSpanish forces and the French were rare and indecisive. Clausewitz's "single stroke" should be understood in much the same way as Mao Zedong conceives the final stage of guerrilla warfare in which guerrillas are strong enough to wage an offensive conventional campaign against government forces about to collapse.

${ }^{34}$ Clausewitz, On War, p. 580.

${ }^{35}$ Ibid.

${ }^{36}$ Ibid., p. 581.

${ }^{37}$ Ibid.

${ }^{38}$ This point is later made by Mao Zedong who suggests that the third stage of guerrilla warfare requires the guerrilla to turn to conventional conflict to strike the decisive blow. See Mao Tse-Tung and Samual B. Griffith (trans), On Guerrilla Warfare (Urbana-Champagne: University of Illinois Press, 2000) Chapters 2 and 4.

${ }^{39}$ Clausewitz, On War, p. 581.

${ }^{40}$ Ibid., p.582. In his discussion of offensive and defensive warfare, Yitzhak Klein illustrates the difficulty conventional forces have in fighting the type of war advocated by Clausewitz. As Klein points out, “... military establishments tend to prefer offensives because planning offensives creates an impression of control over the course of events and because successful offensives make things happen in a particular way-they compel." Yitzhak Klein, "Long Defensives: Victory without Compellence", Comparative Strategy 15 (1996) pp. 233-249. 
${ }^{41}$ Peter R. Moody, "Clausewitz and the Fading Dialectic of War", World Politics 31, no. 3 (1979) pp.417-433; Edward M. Collins, "Clausewitz and Democracy's Modern Wars", Military Affairs 19, no. 1 (1955) pp. 15-20.

${ }^{42}$ The People's Republic of China is widely viewed within the US Department of Defense as the next challenger to American military supremacy. While this is probably true, China is not the former Soviet Union. In the decades to come, China is likely to seek to reassert itself as a regional hegemon in Asia, but unlikely to pose a threat to the United States.

${ }^{43}$ For examples of the micro-scale conflicts of the past, see Max Boot, The Savage Wars of Peace: Small Wars and the Rise of American Power (New York: Basic Books, 2003).

${ }^{44}$ Louis Hansen, "Command Will Give Sailors a Larger Role on the Ground", The Virginian-Pilot (Norfolk, VA.: January 14, 2006). Available online at http://content.hamptonroads.com/story.cfm?story $=98139 \&$ ran $=183893$ Accessed 22 November 2007. 